\title{
PENGGUNAAN METODE STEPWISE PADA PEMODELAN PERENCANAAN TRACK QUALITY INDEX (TQI)UNTUK KERETA API SEMICEPAT INDONESIA
}

\author{
Alfisyahrina Hapsery ${ }^{1}$, Reysha Rizki Amanda Lubis ${ }^{2}$ \\ ${ }^{1}$ Universitas PGRI Adi Buana Surabaya \\ ${ }^{2}$ Institut Teknologi Sepuluh Nopember Surabaya \\ alfisyahrina@unipasby.ac.id ${ }^{1}$, reyshalubis79@gmail.com ${ }^{2}$
}

\begin{abstract}
ABSTRAK
Dalam analisis regresi, salah satu asumsi yang harus dipenuhi adalah tidak adanya hubungan antar variabel independen. Hubungan yang kuat antar variabel independen disebut dengan multikolinieritas. Berbagai metode dapat menanggulangi kasus multikolinieritas, semua itu bergantung pada tujuan dari penelitian. Beberapa metode tersebut adalah ridge regression, principal component regression, regresi robust dan pemilihan model terbaik. Pada penelitian ini, metode pemilihan model terbaik dipilih untuk digunakan karena bertujuan untuk menentukan variabel independen yang signifikan dengan mempertimbangkan korelasi parsial pada data track quality index (TQI) kereta api Indonesia. Untuk mengukur besarnya TQI diperlukan empat indikator yang kemudian menjadi variabel dalam penelitian ini, yaitu lebar jalur, angkatan, listringan dan pertinggian. Hasil analisis menunjukkan variabel pertinggian, angkatan dan listringan berpengaruh besarnya nilai TQI dengan variasi data yang dapat dijelaskan model sebesar $99,7 \%$.
\end{abstract}

Kata kunci: multikolinieritas, stepwise, track quality index.

\begin{abstract}
In regression analysis, one of the assumptions is the absence of relationships between independent variables. Relationship between independent variables is called multicollinearity. Various methods can overcome multicollinearity cases, all of which depend on the purpose of the study. Some of these methods are ridge regression, principal component regression, robust regression and selection of the best models. In this study, the best model selection method was chosen because it aims to determine significant independent variables taking into account the partial correlation of track quality index (TQI) data. To measure the magnitude of TQI, four indicators are needed which then become the variables in this study, namely the width of the track, force, lightning and elevation. The results of the analysis show that the height, force and list
\end{abstract}




\section{Alfisyahrina Hapsery, Reysha Rizki Amanda Lubis}

variables influence the magnitude of the TQI value with variations in the data that can be explained by the model by $99.7 \%$.

Keywords: multikolinierity, stepwise, track quality index.

\section{PENDAHULUAN}

Multikolinieritas merupakan permasalahan yang sering dijumpai pada pemodelan data. Masalah utama pada kasus multikolinieritas adalah adanya hubungan antar variabel independen. Hal ini dapat menyebabkan pemodelan menjadi bias dan tidak dapat dipertanggungjawabkan kebenarannya (Gujarati, 2004). Pemodelan yang digunakan dalam penelitian perencanaan track quality index (TQI) untuk kereta api semicepat ini menggunakan metode regresi linier berganda. Syarat utama dalam hal pemodelan pada metode regresi linier berganda adalah tidak terjadi kasus multikolinieritas.

Multikolinieritas dapat ditanggulangi dengan beberapa metode, bergantung pada tujuan dilakukan pemodelan. Peneliti dapat menggunakan metode pemilihan model terbaik yaitu stepwise apabila ingin mendapatkan model, mengetahui variabel yang berpengaruh dan memprediksi nilai TQI berdasarkan faktor yang mempengaruhinya. Cara lain yaitu dengan menggunakan Principle component analysis (PCR) untuk mendapatkan model dan memprediksi dengan variabel independen yang digunakan sudah ditetapkan (Draper \& Smith, 2014). Secara teori variabel tersebut merupakan faktor yang menentukan besarnya variabel dependen. Dalam kasus ini, peneliti akan menggunakan metode stepwise dengan harapan untuk mengetahui variabel independen mana yang mempengaruhi besarnya nilai TQI dan menanggulangi adanya asumsi multikolinieritas. Metode stepwise merupakan satu diantara empat metode yang dapat digunakan untuk memilih model terbaik.

Metode stepwise merupakan metode alternatif dalam analisis regresi yang membantu proses analisis untuk mendapatkan model yang memberikan kontribusi tinggi (Wohon et al, 2017). Berbeda dengan ketiga metode pemilihan yang lain, metode stepwisememperhitungkan korelasi parsial sebagai prosedur dalam analisis. Korelasi parsial dihitung dari residual hasil meregresikan antar variabel independen yang satu dengan yang lain. Kriteria pemilihan model pada umumnya sama yaitu dengan melihat nilai R-sq yang cenderung stabil dimana nilai s yang dihasilkan mendekati nilai varians data tersebut. Metode ini sesuai dengan 
karakteristik data track quality indexuntuk perencanaan kereta api semicepat yang digunakan dalam penelitian ini.

Perencanaan kereta semicepat tidak lepas dari prediksi besarnya nilai TQI, yang secara teori dipengaruhi oleh berbagai faktor. Diantaranya yaitu lebar jalur, angkatan, listringan, pertinggian dan kecepatan kereta api (Alamsyah, 2003). Lebar jalur pada kereta api diukur melalui lebar sisi dalam kepala rel pada jalur lintasan kereta. Untuk pertinggian terdapat pengukuran dilakukan dengan melihat tinggi dari kepala rel bagian kiri dan kanan harus sama. Pada variabel listringan dilakukan maintenanceketika terjadi ketidaklurusan sebesar $5 \mathrm{~mm}$. berbeda dengan variabel angkatan dilakukan perbaikan ketika terjadi penurunan tinggi dari kepala rel sebesar $7 \mathrm{~mm}$ (Kurniawan, 2015).

Perencanaan kecepatan pada kereta api semicepat di Indonesia berkisar antara 160 km/jam seperti yang dijelaskan menteri perhubungan Budi Karya Sumadi dalam keterangan pada 3 Desember 2016. Penentuan kecepatan kereta tidak memiliki klasifikasi khusus, setiap negara berbeda-beda karena memiliki lintasan yang berbeda pula. Beberapa negara yang telah menggunakan kereta semicepat adalah India, Jepang, dan Spanyol. Tingkat kecepatan kereta api yang digunakan Negara India yaitu 160-240 km/jam, Jepang sebesar 130-200 km/jam, dan Negara Spanyol berkisar antara 160-200 km/jam (Eesveld, 1989). Berdasarkan adanya perencanaan ini, ingin diketahui besarnya nilai TQI berdasarkan faktor yang mempengaruhi kondisi rel di Indonesia. Penelitian ini bertujuann membantu PT. KAI dalam menentukan rekomendasi besarnya TQI yang tepat untuk kereta api semicepat yang akan dioperasikan di Indonesia.

\section{METODE PENELITIAN}

Data pada penelitian ini adalah data sekunder yang diperoleh dari PT. KAI dalam perencanaan kereta semicepat dengan cara mengukur track geometri kereta tahun 2018. Menurut hasil perencanaan, kereta semicepat iniakan dioperasikan di Indonesia. Variabel Independen yang digunakan adalah lebar jalur, angkatan, listringan, pertinggian dan kecepatan. Jumlah data pada penelitian ini sebanyak 160 data dari beberapa wilayah yang telah dilalukan sampling. Sedangkan variabel dependen yang digunakan adalah nilai TQI. Langkah analisis atau 
tahapan yang dilakukan terdiri dari tiga tahap, yaitu tahap eksplorasi data dan pemodelan data sebagai berikut:

1. Melakukan eksplorasi data untuk melihat karakteristik data kereta yang tersedia.

a. Melakukan pemeriksaan hubungan antar variabel, baik variabel independen maupun dependen dengan menggunakan scatter plot

b. Melakukan pemeriksaan multikolinieritas dengan menggunakan nilai korelasi

2. Memodelkan faktor-faktor yang mempengaruhi besarnya TQI pada kereta api.

a. Mengestimasi parameter model regresi hasil analisis.

b. Melakukan pengujian parameter secara serentak untuk mengetahui signifikansi koefisien model.

c. Menguji parameter secara individu. Jika terdapat variabel yang tidak signifikan, maka dilakukan penanggulangan menggunakan metode stepwise.

d. Mengukur kebaikan model melalui perhitungan koefisien determinasi.

e. Melakukan pengujian asumsi identik menggunakan uji white.

f. Melakukan pemeriksaan asumsi independen menggunakan plot antara residual dengan hasil prediksi.

g. Melakukan pengujian asumsi distribusi normal menggunakan KolmogorovSmirnov.

h. Interpretasi model regresi.

3. Prosedur pemilihan metode terbaik dengan menggunakan stepwise. Metode ini dilakukan dengan meregresikan masing-masing variabel independen dengan langkah :

a. Hitung koefisien korelasi antara variabel independen dengan variabel dependen.

b. Pilih variabel independen yang mempunyai korelasi tertinggi dengan variabel dependen.

c. Kemudian, regresikan antar variabel independen sehingga mendapatkan nilai korelasi parsial.

d. Lakukan pengujian parameter secara serentak dan parsial. Apabila hasil pengujian menyimpulkan bahwa variabel independen berpengaruh, maka 
tambahkan variabel independen tertinggi berikutnya. Apabila sebaliknya, maka hilangkan variabel independen tersebut dari model.

e. Langkah selanjutnya, lakukan langkah pertama hingga keempat (Ilmi \& Parta, 2013).

Keputusan untuk memilih model regresi terbaik dimana seluruh variabel signifikan, harus memenuhi beberapa kriteria yaitu: perubahan nilai $\mathrm{R}^{2}$ menjadi lebih baik, S cenderung stabil dan mendekati nilai varians yang sebenarnya, dan Mallow $C_{p}$ serendah mungkin hingga mendekati atau sama dengan $p$ (Draper and Smith, 1992). Korelasi yang digunakan dalam metode stepwise adalah korelasi parsial. Korelasi tersebut melibatkan korelasi antara residual $\left(\varepsilon_{y}, \varepsilon_{k}\right)$ data dimana variabel independen juga menjadi variabel dependen dalam pemodelan selanjutnya.

\section{HASIL PENELITIAN DAN PEMBAHASAN}

Sebelum melakukan pemodelan faktor-faktor yang mempengaruhi TQI pada kereta api Indonesia, terlebih dahulu dilakukan pendeteksian hubungan antar variabel menggunakan scatter plot seperti yang terlihat pada Gambar 1 plot yang terbentuk tidak mengikuti pola linier. Pola data yang terlihat yaitu data menggerombol dipojok kiri bawah hampir di semua variabel. Hubungan diantara variabel independen disebut multikolinearitas. Dalam analisis regresi hubungan antara variabel independen tidak diijinkan. Berikut adalah hasil perhitungan koefisien korelasi antara kedua variabel.

Tabel 1. Matriks Korelasi antar Variabel Independen

\begin{tabular}{lrrrrr}
\hline Variabel independen & Kecepatan & Lebar jalur & Pertinggian & Angkatan & Listringan \\
\hline Kecepatan $\left(X_{1}\right)$ & 1,000 & & & & \\
Lebar jalur $\left(X_{2}\right)$ & $\mathbf{- 0 , 4 6 0}$ & 1,000 & & & \\
Pertinggian $\left(X_{3}\right)$ & $\mathbf{- 0 , 8 7 1}$ & $\mathbf{0 , 5 3 7}$ & 1,000 & & \\
Angkatan $\left(X_{4}\right)$ & $\mathbf{- 0 , 4 6 2}$ & 0,158 & $\mathbf{0 , 1 8 9}$ & 1,000 & \\
Listringan $\left(X_{5}\right)$ & $\mathbf{- 0 , 4 5 3}$ & $\mathbf{0 , 3 0 1}$ & $\mathbf{0 , 2 8 6}$ & $\mathbf{0 , 5 1 8}$ & 1,000 \\
\hline
\end{tabular}

Catatan : Data yang dicetak tebal signifikan pada $\alpha=0,05$.

Untuk mengetahui ada dan tidaknya hubungan antar variabel independen dilakukan dengan cara menghitung nilai korelasi. Nilai korelasi dapat menggambarkan hubungan antara dua variabel independen berdasarkan nilai 
signifikan. Pada nilai tersebut diketahui lebih kecil dari 0,05, sehingga dapat disimpulkan bahwa seluruh variabel memiliki hubungan. Untuk variabel angkatan tidak memiliki hubungan dengan variabel lebar jalur pada kereta api seperti yang terlihat pada Tabel 1. Selain itu, multikolinieritas juga diduga karena adanya perubahan tanda positif dan negative pada koefisien regresi dan korelasi. Nilai koefisien regresi dapat dari model pada variabel kecepatan memiliki nilai positif, sedangkan koefisien korelasi memiliki nilai negatif. Hal ini merupakan pembuktian kedua yang membuktikan adanya kasus multikolinieritas.
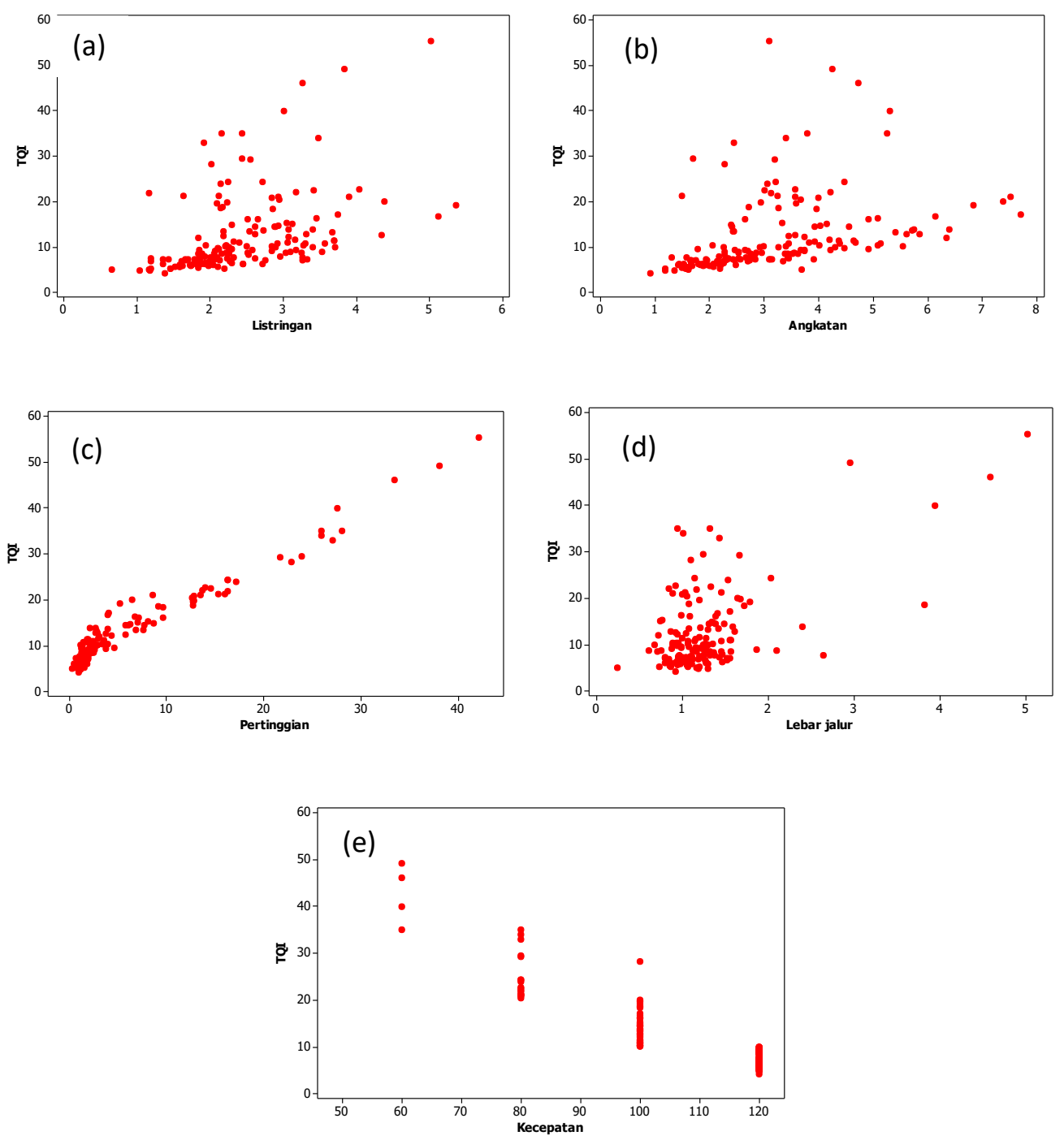

Gambar 1. Scatter Plot (a) Variabel Listringan dengan TQI, (b) Variabel Angkatan dengan TQI, (c) Pertinggian dengan TQI, (d) Lebar Jalur dengan TQI, (e) Kecepatan dengan TQI. 
Dalam kasus multikolinieritas, terdapat banyak cara untuk mendapatkan model. Metode alternatif untuk kasus ini yaitu dengan melakukan pemilihan model terbaik. Pemilihan model terbaik yang dipilih adalah metode stepwise karena dalam proses interaksinya terdapat korelasi parsial.Prosedur pemilihan model terbaik pada metode stepwise dengan mensuptitusikan masing-masing variabel independen berdasarkan nilai koefisien korelasi tertinggi. Hasil estimasi parameter dengan menggunakan metode stepwise dapat dilihat pada Tabel 2 berikut

Tabel 2. Koefisien Determinasi dan Pengujian Parsial Metode Stepwise

\begin{tabular}{|c|c|c|c|c|}
\hline \multicolumn{2}{|l|}{ Step 3} & & & \\
\hline $\mathrm{S}$ & 0,5088 & & & \\
\hline $\mathrm{R}$-sq & 0,997 & & & \\
\hline R-sq (adj) & 0,997 & & & \\
\hline Variabel & B & Std. Error & $\mathbf{t}$ & $p_{\text {value }}$ \\
\hline Constant & 0,766 & 0,133 & 5,751 & 0,000 \\
\hline Pertinggian $\left(\mathrm{X}_{3}\right)$ & 1,039 & 0,005 & 189,360 & 0,000 \\
\hline Angkatan $\left(\mathrm{X}_{4}\right)$ & 0,989 & 0,034 & 28,883 & 0,000 \\
\hline Listringan $\left(X_{5}\right)$ & 1,130 & 0,060 & 18,978 & 0,000 \\
\hline
\end{tabular}

Estimasi parameter yang dihasilkan pada Tabel 2 memberi informasi bahwa hanya tiga variabel independen yang signifikan. Pemilihan model terbaik pada metode stepwise dengan melihat penambahan $\mathrm{R}^{2}$ (adj) disetiap step. Variabel yang berpengaruh terhadap TQI adalah Pertinggian, Angkatan, dan Listringan.Kebaikan model regresi dapat diketahui dengan menggunakan koefisien determinasi, yangmenjelaskan proporsi dari variasi total TQI yang dapat dijelaskan oleh variabel independen.

Tabel 3. Step Pemilihan Model Terbaik Menggunakan Stepwise

\begin{tabular}{cccc}
\hline Step & S & R-sq & R-sq (adj) \\
\hline 1 & 2,003 & 0,948 & 0,947 \\
2 & 0,922 & 0,989 & 0,989 \\
3 & 0,509 & 0,997 & 0,997 \\
\hline
\end{tabular}

Tabel 3 pada step ketiga diketahui nilai R-sq yang menunjukkan variabilitas data. Besarnya variabilitas TQI yang dapat dijelaskan oleh pertinggian, angkatan dan listringan sebesar 99,7\%. Interpretasi berikut dilakukan untuk mengetahui seberapa besar ketiga faktor berpengaruh terhadap TQI dengan model

$$
T Q I=0,766+1,039 \text { Pertinggian }+ \text { 0,989Angkatan }+1,130 \text { Listringan }
$$


Persamaan tersebut adalah persamaan untuk model regresi TQI. Interpretasi model untuk variabel pertinggian yaitu apabila pertinggian pada lintasan bertambah sebesar satu satuan maka TQI bertambah sebesar satu satuan, dengan syarat variabel lainnya dianggap konstan. Untuk variabel angkatan yaitu rata-rata nilai TQI kereta api akan bertambah sebesar 6,9 ketika angkatan pada lintasan bertambah sebesar $7 \mathrm{~mm}$, dengan syarat pertinggian dan listringan konstan. Dan untuk variabel listringan yaituapabila listringan bertambah sebesar $5 \mathrm{~mm}$, maka nilai TQI bertambah dengan rata-rata 5,6.

\section{SIMPULAN}

Pada analisis perencanaan kereta semicepat dengan metode stepwise diketahui bahwa variabel yang menjadi faktor adalah pertinggian, angkatan dan listringan berdasarkan nilai korelasi parsial. Variabilitas data yang dapat dijelaskan sebesar 99,7\%. Informasi ini dapat membantu dalam proses perencanaan kereta semicepat bahwa besarnya nilai TQI sudah dapat ditentukan dengan menggunakan tiga indikator saja. Saran dalam penelitian ini, untuk analisis selanjutnya apabila ingin diketahui pengaruh kecepatan terhadap besarnya nilai TQI dapat menggunakan metode Backward. Selain itu, jika ingin menggunakan kelima variabel independen untuk memprediksi besarnya nilai TQI dapat menggunakan metode PCR.

\section{DAFTAR PUSTAKA}

Alamsyah, A. A. (2003). Rekayasa Jalan Rel. Malang: Bayumedia.

Draper, N. R., \& Smith, H. (2014). Applied regression analysis. John Wiley \& Sons.

Eesveld, C. (1989), Modern Railway Track. Delft: Graphics Department of Thyssen Stahl AG.

Gujarati, D.N. (2004). Basic Econometrics $\left(4^{\text {th }}\right.$ ed). United Stated of America: The McGraw-Hill Companies.

Ilmi, N. H., \& Parta, I. N. (2013). Penerapan metode Regresi new Stepwise untuk Mengetahui Faktor- faktor yang mempengaruhi Kekuatan Metallic Box. Malang: Universitas Negeri Malang.

Kurniawan, W., \& Rulhendri, (2015). Tinjauan Volume Pemeliharaan Tahunan Jalan Rel Berdasarkan Hasil Track Quality Index (TQI). Jurnal Rekayasa Sipil, 4(2), 1-17.

PT. KAI. (2017). Peraturan Dinas Nomor 10A Tentang Perawatan Jalan Rel Dengan Lebar 1067 mm, PT. KAI: Bandung. 
Penggunaan Metode Stepwise pada Pemodelan Perencanaan Track Quality Index (TQI) untuk Kereta Api Semicepat Indonesia

Wohon, S. C., Hatidja, D., \& Nainggolan, N., (2017). Penentuan Model Regresi Terbaik dengan Menggunakan Metode Stepwise. Jurnal Ilmiah Sains, $17(2), 80-88$. 